\title{
Tracing and Mapping of Cultural Reserves as a Source of Information for Historical Tourism in Langsa City
}

\author{
Bukhari $^{1}$, Madhan Anis ${ }^{2}$, Ramazan $^{3}$ \\ 1,2,3 Univesitas Samudra, Indonesia \\ bukhari@unsam.ac.id,madhan.anis@unsam.ac.id,ramazan@unsam.ac.id
}

\begin{abstract}
Cultural heritage objects are evidence of historical heritage that is very useful in life, cultural heritage is also useful as a means of education as well as a historical tourism destination for the community. The purpose of this research is to find out historical heritage buildings in Langsa City, then to map the historical heritage buildings to be used as sources of information. The method in this study uses a historical method with stages namely the heuristic stage, the source criticism stage, the interpretation stage and the historiography stage. The result of the research is that there are five historical heritage buildings in Langsa City that have been designated as a Cultural Heritage with the Letter of the Mayor of Langsa in 2016. Then the mapping is carried out on the historical heritage which has been used as a source of information that is very helpful for local, regional, national and foreign tourists who visit Langsa City.
\end{abstract}

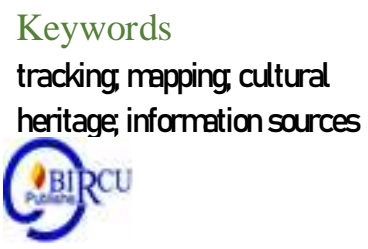

Keywords

tracking, mapping, cultural heritage, information sources

\section{Introduction}

History is a process of human struggle in achieving a scientifically structured description of all its activities by paying attention to the time sequence, given critical interpretation and analysis so that it is easy to understand and understand. History can provide an overview of human actions and actions with all the changes (Susanto, 2014: 7).

History leaves traces that are called historical relics. Historical heritage becomes a historical legacy that is a very valuable asset of the nation and if it is properly preserved it can be of use for future generations. According to Ida Bagus NyomanWartha (2016: 191) functions of historical and ancient heritage, among others, as a medium for national cultural education, and a medium to foster national personality in the field of culture and national resilience. Furthermore, in the explanation above, it is a historical relicsa proof ofhistorical events yang very beneficial and play an important rolein social life inherited by their ancestors. Therefore, it really needs to be preserved and maintained as a medium to foster national personality and national resilience.

Cultural Heritage Objects are evidence of historical / archaeological heritage that is very useful in social life which is inherited by ancestors from generation to generation. Therefore, it really needs to be preserved and maintained as a medium to cultivate historical awareness. One area that has a lot of potential historical heritage is Langsa City. Langsa City is a division of East Aceh Regency, and Langsa City was previously designated as an administrative city (Kotif) which later became Langsa City. The juridical basis for the formation of Langsa City is Law Number 3 of 2001 which was inaugurated on June 21, 2001 (Rachmatsyah, 2014).

Langsa is a small city that has many historical relics, so Langsa city should be suitable to be promoted as a city for historical tourism. Langsa is known for its historical heritage. The existence of historical relics in Langsa city should make the public aware of 
their existence, know information about historical relics, and become aware of the benefits of these historical relics. With these historical relics, the community can also play a role as a pioneer to save historical relics, especially those around the area where they live, so that it will indirectly raise historical awareness in the community. To achieve this, it is necessary to trace and map these historical relics.

\section{Review of Literatures}

\subsection{Cultural Heritage}

In some areas it must have cultural heritage. Usually the cultural heritage becomes an icon of an area, and can also be used as a tourist visit in an area. In Law Number 11 concerning Cultural Heritage, it is stated that cultural heritage is a material cultural heritage in the form of cultural heritage objects, cultural heritage buildings, cultural heritage structures, cultural heritage sites and cultural heritage areas both on land and in the wild, it is necessary to preserve its existence because has an important value for history, science, religious education and culture through the process of determination.

According to Korumaz in Atalan $(2018,1701)$ the concept of cultural heritage is as follows:

"The concept of Cultural Heritage has become today with developing in terms of definition and scope in the historical time. Cultural heritage is limited only to important monumental structures in the early days of the formation process of the conservation notion. In the later processes the scope of the conservation notion has expanded, it encompasses civilian structures as well as urban and rural areas. The scope of cultural heritage has also been developed, including intangible work of branches of culture and art".

Based on the above quotation, cultural heritage developed only within the scope of important monument structures, but the subsequent process expanded its scope to include civil structures as well as urban and rural areas. Then developed in terms of intangible works such as culture and art.

\subsection{Resources}

In human life, we really need information in every day's activities. There are many available sources of information that exist and develop in the community. According to Notoatmodjo (2003), information sources are anything that acts as an intermediary in conveying information, information media for mass communication. Sources of information can be obtained through print media such as newspapers or magazines, electronic media such as television, radio and the internet.

In line with the above, the source of information is something that is around the environment that can functionally be used to help provide information for those in need (Putri, 2018: 20). Usually the source of information is widely used for someone who wants to travel to several tourism destination areas.

\subsection{Historical Tour}

Tourism is an activity that people often do to release boredom after being tired of work. According to the Ministry of Tourism based on Law Number 10 of 2009 concerning Tourism Chapter 1 Article 1 states that tourism is: "Travel activities carried out by a person or group of people by visiting certain places for recreational purposes, personal development, or learning the uniqueness of tourist attractions visited in a temporary period". 
There are many types of tourism, one of which is historical-based tourism, according to Suyatmin (2014) history-based tourism is one of the potentials that are generally owned by each region, which makes the area different from other regions and even becomes a characteristic or characteristic of the region.

In line with this, according to Bruce.G in Kartika et al (2017: 39) for historical tourism, it is "is a personal encounter with traditions, history, and culture. Heritagetourism is based upon the concept that each community has a story to tell", which means that a person traveling meets several things such as tradition, culture and history.

\section{Research Methods}

This type of research is historical research in which the method used is historical research methods. The historical method is a study and other sources that contain information about the past and is carried out systematically. The process of historical research consists of investigating, explaining and understanding activities or events that occurred some time ago to discover the truth. The historical method itself has four sequential steps: heuristics, criticism, interpretation, and historiography (Gottschalk, 2008: 39).

The research was carried out in stages according to the research method used, namely the historical method. Researchers used the research stages as expressed by Sjamsuddin (2007: 85-155), namely collection of sources (heuristics), source criticism (verification), interpretation (interpretation) and historical writing (historiography).

Heuristics is a technique of finding sources. Based on the form of presentation, historical sources consist of archives, documents, books, magazines / journals, newspapers, and others. Currently, historical data can be obtained from various ways besides literature study, historical sources can also be accessed through print and electronic media. Most importantly, a researcher must know how to handle historical evidence and how to relate it (Alian, 2012: 9-10). In order for the search for sources to take place effectively, two supporting elements of the heuristic must be considered, namely: a) the search for sources must be guided by the framework, and pay attention to the problems implied in the written framework (chapters and sections), the researcher knows the sources that have not been found . b) In searching for sources in the library,

In using historical sources, one must evaluate or criticize the sources used. Source criticism is the process of testing the source, whether the source stated is genuine or false (external criticism) and whether it can be trusted or justified or not. There are two kinds of criticism, namely: External Criticism and Internal Criticism. External criticism is investigating to determine authenticity by answering questions $5 \mathrm{~W}+1 \mathrm{H}$. Meanwhile, internal criticism is the determination of whether the information in the document can be used as historical facts (Yass, 2004: 35-36). So it can be concluded that internal criticism is carried out to seek the authenticity of the content of the source or data in order to obtain a truth or error that occurs,

Interpretation states that interpretation analyzes historical data. With this interpretation the writer tries to connect the facts or tries to be able to provide an interpretation of what is in the writing of this research report. (Kuntowijoyo, 1994: 100). Interpretation of facts must be based on an objective attitude. Even if in certain cases be subjective rational and not emotional subjective. The reconstruction of historical events must produce history that is true or closer to the truth.

Historiography is weaving together facts and their meanings chronologically / diachronic and systematically, into historical writing as a story. The two characteristics of 
the description must be clearly seen, because they are part of the characteristics of scientific history work, as well as the characteristics of history as science. Historiography is also a combination of artistic work (art) and the ability to think critically and analytically (science) (Gottschalk, 2008: 39-40).

\section{Results and Discussion}

\subsection{Historical Heritage Buildings in Langsa City}

The results of the search carried out were obtained data of historical heritage buildings scattered in Langsa City. These data are obtained from research conducted at the Head of History and Tradition under the Langsa City Education and Culture Office. These historical heritage buildings are scattered in several locations in the center of Langsa City. These historical heritage buildings have their own stories which are quite interesting to be studied further.

These historical heritage buildings have already been designated as cultural heritage based on the Langsa Mayor's Decree, namely there are 5 historical heritage buildings including Balee Juang, SD Negeri 1 Langsa, PDAM, Pendopo and Satpol PP Building Langsa City. The further explanation regarding historical heritage buildings in Langsa City is as follows:

\section{a. Balee Juang Building Ex Bappeda East Aceh (Langsa Museum Building)}

Langsa museum building, estimated to have been built in the early 20th century or around the 1910s. This building is thought to have been built for the first time to support the better industrial plantation offices in the Aceh region at that time. In 1945 during the era of the war for independence, this building was used by the fighters as one of the buildings where they held meetings to organize resistance to the Japanese and Dutch colonialists. With its function at that time, this building was named Balee Juang. After 1945 this building was functioned by a beautiful fertilizer company, it was also used by many student organizations, and in the 1980s this building was officially taken over by the East Aceh Regency Government to become the East Aceh Bappeda office building. In 2014, the East Aceh Regency Government donated the building to Pemko Langsa and then the mayor of Langsa made this building the Langsa Museum Building. This historical heritage building was designated as a cultural heritage building based on the decision of the Mayor of Langsa Number 188/430/2016 which was established in Langsa on 7 March 2016 by the Mayor of Langsa Usman Abdullah.

\section{b. SD Negeri 1 Langsa}

SD Negeri 1 Kota Langsa Building is located on Jl. Cut Nyak Dhien, Gampong Jawa, Langsa City District, Langsa City. This building is estimated to have been built in 1910 with a function as a Special Military Hospital or the Dutch Colonial Military family in Langsa. The architecture of the building is in the form of a single elongated building containing ward rooms that can accommodate an estimated 20 beds. This historical heritage building was designated as a cultural heritage building based on the decision of Mayor Langsa Number 189/430/2016 which was established in Langsa on March 7, 2016 by Mayor Langsa Usman Abdullah. 


\section{c. PDAM Tirta Keumueneng Water Tower}

PDAM Langsa City Water Tower was built in 1928 along with a clean water facility building in Keumueneng. This tower became the center of the water channel that was distributed to buildings, offices and settlements during the Dutch colonial era. The architectural feature of the tower is in the form of a tower with cast pillar supports that support the load of the water reservoir. It is estimated that the water capacity stored is around 50,000 liters. This historical heritage building was designated as a cultural heritage building based on the decision of the Mayor of Langsa Number 190/430/2016 which was established in Langsa on 7 March 2016 by Mayor Langsa Usman Abdullah.

\section{d. Pendopo Building}

The Pendopo Langsa building is estimated to have been built in the early 20th century or around the 1910s at the same time that security in Aceh was generally more conducive. This building is the official residence as well as the office building of Dutch officials who govern the government in Langsa spare parts which oversees a large area including Manyak Payed, Sungai Raya, Peureulak to Lokop and Serbajadi East Aceh. This historical heritage building was designated as a cultural heritage building based on the decision of Mayor Langsa Number 186/430/2016 which was established in Langsa on March 7, 2016 by Mayor Langsa Usman Abdullah.

\section{e. Satpol PP Langsa Building}

The Satpol PP \& WH Office Building of Langsa City, is estimated to have been built in the early 20th century or around the 1910s along with the construction of the Langsa museum building. Based on information from local residents, this building was built as a direct train office. This historical heritage building was designated as a cultural heritage building based on the decision of the Mayor of Langsa Number 187/430/2016 which was established in Langsa on 7 March 2016 by Mayor Langsa Usman Abdullah.

\subsection{Mapping of the Distribution of Cultural Heritage in Langsa City}

Langsa City is one of the cities built by the Dutch colonial government with the aim of accommodating the interests of foreign capitalism through the establishment of industrialization of the plantation sector and exploitation of agricultural products. Industrialization is a key factor in the occurrence of many changes in Aceh after the colonial era, especially after the Aceh war 1873-1912). Through industrialization, the Netherlands began to apply the capitalist system as the basis for its new economy.

According to Ismail, Langsa (onderafdeeling Langsa) and Kualasabung (onderafdeeling Tamiang) emerged as new cities since Industry was present in East Aceh in the first decade of the 20th century, so these findings prove that East Aceh is a very important area (Muhajir, 2017: 64 ).

In a short time, it became a big city which was vital enough to exist until the end of Dutch colonialism. Various infrastructures were built, so it is not surprising if it then immediately became a colonial city filled with legacy of typical Dutch-style buildings. This infrastructure is very much needed to support industrialization, both urban-based and rural-based industries, both of which are interrelated.

Industry in urban areas which includes the transportation service industry, communication services and public services that were built by the colonial government to support industry in rural areas. Industry in rural areas includes the rubber plantation and petroleum mining industries which are dominated by private capitalists. The rural industry developed in Langsa is a type of upstream industry that produces products in the form of 
semi-finished goods, especially latex and crude oil, which are then sent to upstream industrial areas both at home and abroad. Industrialization has an impact on the growth of Langsa's urban space, which indicates that the needs and consumption of city dwellers have been met by the existence of supporting facilities.

The downtown area of Langsa Tunong, which was built since 1905, has been equipped with important infrastructure such as tram networks, seaports and roads. In addition, the city center has also been equipped with administrative buildings, city roads, markets and shops, residential areas and factories in a relatively short time. The space for economic activity includes the market shopping area as well as the availability of financial institutions such as pawnshops, credit banks and state cash offices. Space for social activities includes the availability of residential settlements for Europeans, Bumiputra and the Foreign East. The availability of advice on land and sea transportation, health, religious and relaxation facilities is increasingly complementing the needs of urban residents.

According to Muhajir (2017: 70) The colonial government mentioned Langsa Tunong to refer to the new core area of the city, while the original Langsa State was in an area now called Langsa Lama, and the two were not too far away. Comprehensive urban development planning was initiated in 1905 by the Corps of Engineers. Likewise, since 1908, Langsa Tunong was designated as the capital of Afdeeling East Aceh and Onderafdeeling Langsa with a number of buildings and public facilities that complement it so that in a short time Langsa became a bustling and modern colonial city on the east coast of Aceh.

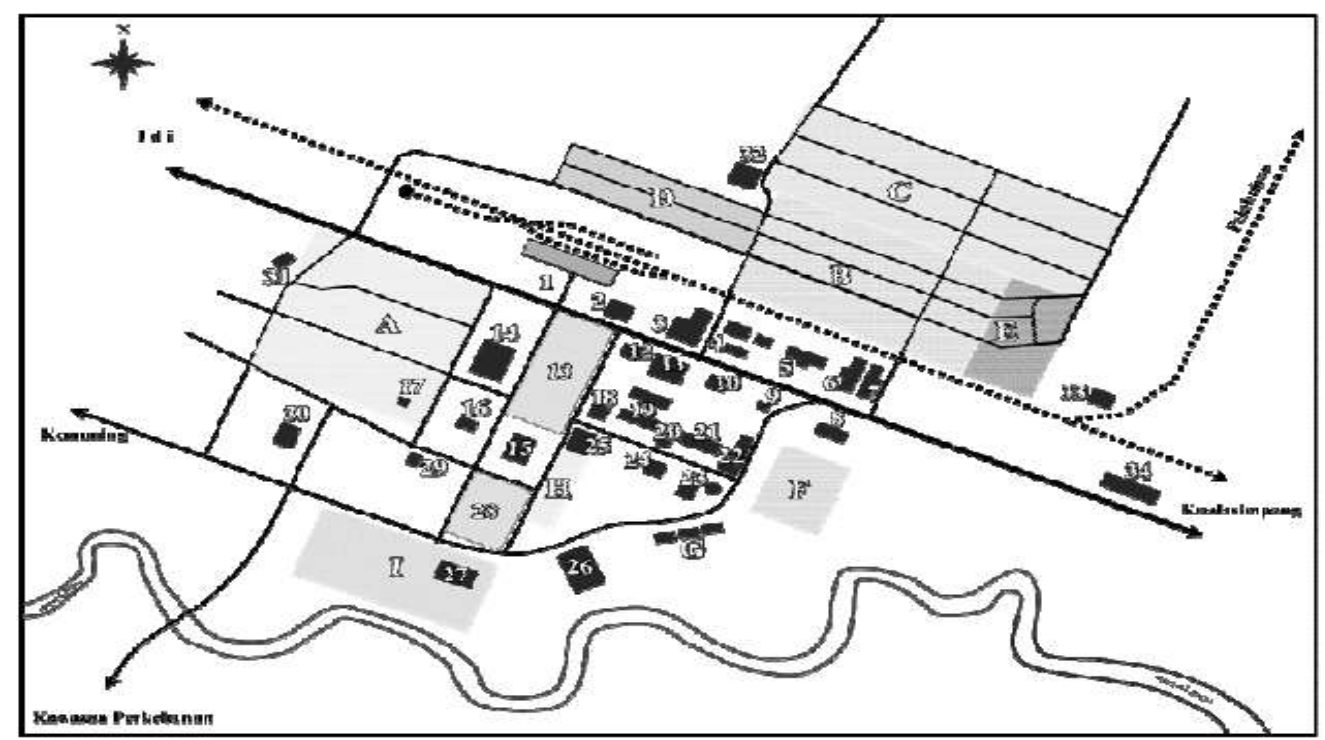

Figure 1. Langsa Tunong Urban Spatial Pattern in the Colonial Era 1907-1942

Source: Adapted from Universiteit Leiden Library, "Town Plane of Langsa, 1944" (online), (http://maps.library.leiden.edu) in Muhajir (2017: 76).

\section{Legend}

$\begin{array}{ll}1 & \text { Aceh Tram Station } \\ 2 & \text { Handel Maatschappij Deli-Atjeh } \\ 3 & \text { Atjehsche Handel Maatschappij } \\ 4 & \text { Kompleks NIGM } \\ 5 & \text { Godown (gudang besar/warehouse ) } \\ 6 & \text { Societeit 'Ons Genoegen' } \\ 7 & \text { Playhouse }\end{array}$

23 Kantor Perusahaan Air

24 Pengadilan dan Markas Polisi

25 Gedung Landraad (Pengadilan Negeri)

26 Penjara

27 Tangsi Militer

28 Lapangan Parade Militer

29 Gereja 
9 Rumah Dokter Sipil Eropa

10 Rumah Dinas Orang Eropa

11 Kantor Pos, Telegraf dan Telepon

12 Kantor Pos Lama

13 Lapangan Serbaguna / Alun-alun

14 Lapangan Tenis

15 Pendopo Asisten Residen

16 Rumah Dinas Komandan Militer

17 Rumah Dinas Dokter Militer

18 Volkscredietbank

19 Komples Sekolah ELS

20 Pegadaian

21 Komplek Sekolah HIS

22 Kompleks Internaat (Asrama Pelajar)
30 Hotel

31 Bengkel Militer

32 Gedung "Oranje Bioscoop"

33 Pusat Distribusi Petrol dan Parafin BPM

34 Kompleks Pabrik Orang Cina

A Europeesche wijk

B Chineezen wijk/Pecinan/Kawasan Pertokoan

C Kampung Melayu

D Kompleks Perumahan Personel Trem

E Kawasan Pasar Tradisional

F Bangsal Rumah Sakit Bumiputera

G Bangsal Rumah Sakit Eropa

H Kompleks Perkantoran Pemerintah

I Kompleks Asrama Militer

Based on the identification by the researchers, some of these buildings are still in accordance with the original, some have been lost or have been restored so that the original buildings are no longer visible. Fortunately, since 2016 the Langsa city government under the leadership of Mayor Usman Abdullah, SE has been concerned about these colonial era buildings. So that these historical heritage buildings have been designated as cultural heritage based on the Langsa Mayor's Decree, namely there are 5 historical heritage buildings including Balee Juang, SD Negeri 1 Langsa, PDAM Tower, Mayor's Hall, and Langsa City Satpol PP Building.

Meanwhile, buildings and sites that have entered the criteria for cultural heritage but have not been determined by the Mayor of Langsa include PTPN I Kebun Lama Area, Post Office, PLN Office, Rock Dormitory (Military Dormitory), SMPN 1 Langsa City, Ulee Balang Gampong Jawa Baro House, Grave Sites The Netherlands "Kerkhoff" Gampong Jawa Rear, Chinatown, Langsa City (Rear Shop), Telaga Tujoh Pusong Area, West Langsa District.

Historical heritage buildings that have been designated as cultural heritage based on the Langsa Mayor's Decree, namely Balee Juang, SD Negeri 1 Langsa, Tower PDAM, Pendopo Mayor, and the Satpol PP Building of Langsa City are in one area, so they deserve to be called a cultural heritage area . Cultural Conservation Area is a geographic space unit having two or more Cultural Conservation Sites which are close together and / or show distinctive spatial characteristics based on Article 1 Paragraph 6.Law of the Republic of Indonesia Number 11 of 2010 concerning Cultural Heritage. Following is a Map of the Cultural Heritage Building Area based on the Langsa Mayor's Decree 


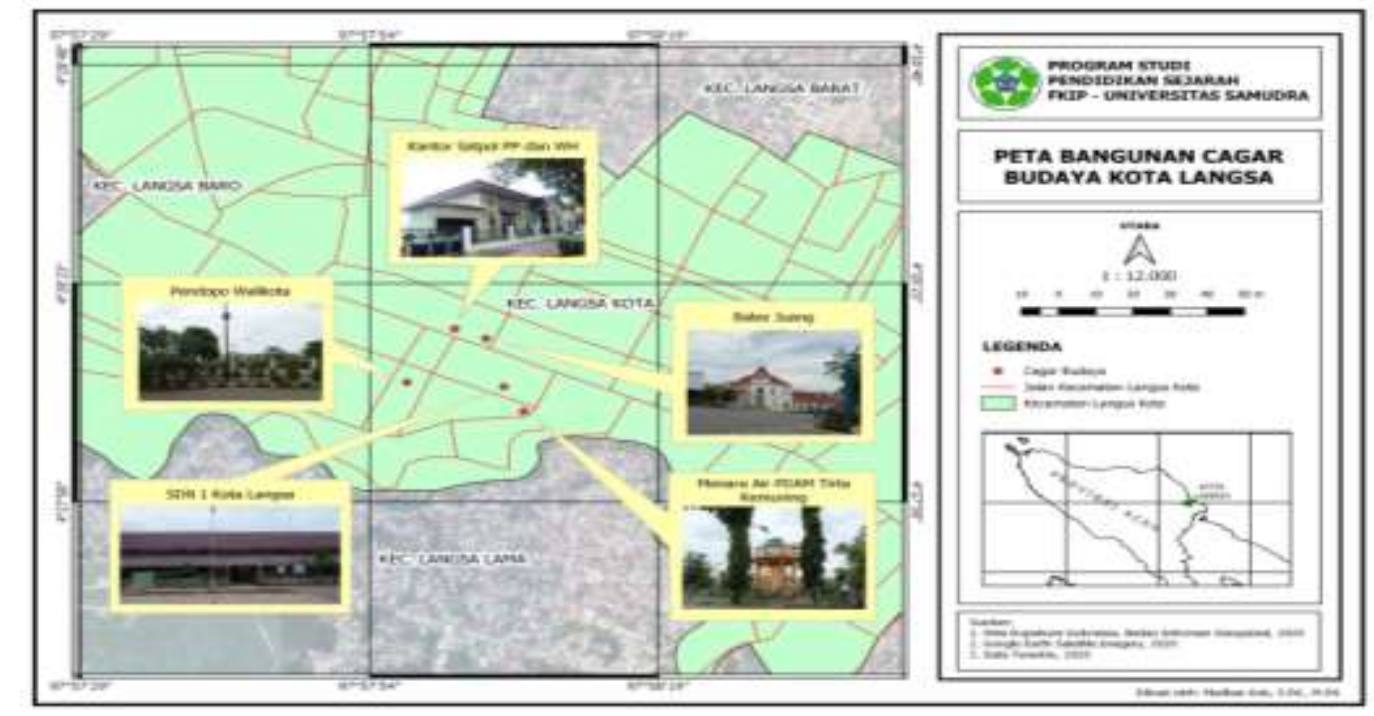

Figure 2. Map of the Cultural Heritage Building Area based on the Langsa Mayor's Decree

\subsection{Sources of Historical Tourism Information Based on the Distribution Map of Cultural Heritage in Langsa City}

History-based tourism is an asset that has the potential to be developed by each region. Each region has different characteristics so that this is its own uniqueness that differentiates it from other regions. This potential is not only related to the interest of spurring local revenue, but will also be a link in the chain for regional economic development. So that areas that are able to develop tourism potential, including historical tourism, will benefit from tourism.

Langsa City is an area that is rich in historical tourism potential, especially when it is related to the existence of the Langsa city area which has many historical values. This is a strategic opportunity for the city of Langsa if historical-based tourism can be developed optimally. So the development of Langsa City as a historical tourism area provides significant benefits to the regional income sector and the informal sector that has emerged and developed in Langsa City as a consequence.

In fact, the historical-based tourism development in Langsa City has not been able to be fully utilized. This is due to various obstacles, so that historical-based tourism is still less marketable. History-based tourism or historical tourism in Langsa City is still less competitive with other tourist charms such as mangrove forest tourism and urban forest tourism which are equipped with educational or recreational games. This, if it continues, will certainly have a negative impact on the continuity of historical-based tourism development and the existence of historical heritage buildings that are prerequisite for historical values.

The problem of physical damage to buildings will affect the degradation of historical values which will have a negative impact on the development of historical tourism. It takes a commitment to the development of historical tourism in a sustainable manner. Management is important and the involvement of a number of parties is a supporting factor that is able to strengthen the historical tourism base in the city of Langsa. The physical condition of the building poses a serious threat to the attractiveness of historical-based tourist destinations. This is the basis for the restructuring of a number of classic buildings in a number of tourist destinations, not only in Indonesia, but also abroad. 
The underlying argument is to maintain and or restore the original form of the building so that it remains a historical-based tourist attraction. However, the orientation and commitment to be able to restore the original form of the building is not easy and funding problems tend to be the classic reasons for the limitations of restructuring buildings in a number of historical-based tourist destinations. This indirectly provides an understanding that the physical condition of the building is an important aspect in supporting the existence of historical-based tourist destinations.

The success or failure of historical-based tourism development does not only refer to the unique physical characteristics of the building, but also the environmental potential that supports the tourist destination itself, in other words the mutual support between the environment and tourist destinations. In addition, promotion is also a reference for the successful development of sustainable tourism and the condition of the building which is the main object that underlies historical tourism attraction because of its uniqueness and physical form that identifies as well as differentiates it from other tourist destinations or in other words the physical condition of the building has a positive effect cultural historybased tourist attraction (Waskito, 2017: 746).

Apart from promoting, there are still many efforts that can be made to develop tourism, especially historical tourism. One of them is mapping cultural heritage buildings as historical tourism information in the city of Langsa. The existence of cultural heritage buildings in the city of Langsa are all located in the center or core of the city. In the colonial era the core area of the city was named Langsa Tunong.

The mapping of historical heritage buildings that has been made has the aim of making local, national and international tourists able to visit some of these historical heritage buildings. So that tourists are not confused in making visits to Langsa City in their tourism activities. The mapping can be used as a source of information for tourists both from outside the city, national and international, because the mapping is made as simple as possible so that all tourists of all ages can read it. Mapping of historical heritage buildings is very good for historical tourism in Langsa City.

\section{Conclusion}

Based on the results of tracing carried out on historical heritage buildings, it was found that some of these buildings were still in accordance with the original, and some were missing or had been restored so that the original buildings were no longer visible. Fortunately, since 2016 the Langsa City government under the leadership of Mayor Usman Abdullah, SE has been concerned about these colonial era buildings. So that these historical heritage buildings have been designated as cultural heritage based on the Langsa Mayor's Decree, namely there are 5 historical heritage buildings including Balee Juang, SD Negeri 1 Langsa, PDAM Tower, Mayor's Hall, and Langsa City Satpol PP Building. Meanwhile, buildings and sites that have entered the criteria for cultural heritage but have not been determined by the Mayor of Langsa include PTPN I Kebun Lama Area, Post Office, PLN Office, Rock Dormitory (Military Dormitory), SMPN 1 Langsa City, Ulee Balang Gampong Jawa Baro House, Grave Sites The Dutch "Kerkhoff” Gampong Jawa Rear, as well as the Chinatown Area of Langsa City (Rear Shop). From the results of the search, a mapping of historical heritage buildings was made. This mapping was made with the hope that through this mapping, it could be used as a source of historical information in historical tourism activities carried out by tourists both local, national and foreign tourists who came to visit Langsa City. Rumah Ulee Balang Gampong Jawa Baro, Dutch Grave Site "Kerkhoff" Gampong Jawa Rear, and Chinatown in Langsa City (Rear Shop). From 
the results of the search, a mapping of historical heritage buildings was made. This mapping was made with the hope that through this mapping, it could be used as a source of historical information in historical tourism activities carried out by tourists both local, national and foreign tourists who came to visit Langsa City. Rumah Ulee Balang Gampong Jawa Baro, Dutch Grave Site "Kerkhoff" Gampong Jawa Rear, and Chinatown in Langsa City (Rear Shop). From the results of the search, a mapping of historical heritage buildings was made. This mapping was made with the hope that through this mapping, it could be used as a source of historical information in historical tourism activities carried out by tourists both local, national and foreign tourists who came to visit Langsa City.

\section{References}

Alian, Sair. (2012). Metodologi Sejarah Dan Histiografi. Palembang: Proyek SP4 Universitas Sriwijaya.

Atalan, Ozlem. 2018. Importance of Cultural Heritage and Conservation Concept in the "Architectural Education". Journal of Human Science. Vol. 15 Issue 3. Hal 17001710 .

Depdiknas. 2010. Undang-Undang RI Nomor 11. Tahun 2010. Tentang Cagar Budaya.

Gottschalk, L. (2008). Mengerti Sejarah. Jakarta: Universitas Indonesia.

Juklat/Lit/01/IV/1973 Tentang pengamanan dan penyelamatan benda-benda purbakala.

Kartika, Titing dkk. 2017. Pengembangan Wisata Heritage Sebagai Daya Tarik Kota Cimahi. Jurnal Manajemen Resort dan Leisure. Vol. 14. No. 2. Hal 35-46.

Kemenpar.2009. Undang-Undang RI No 10 Tahun 2009 tentang Kepariwisataan.

Kuntowijoyo. (1994). Pengantar Ilmu Sejarah. Yogyakarta: Benteng Budaya.

Munandar, Agus Haris. 2013. "Artefak Di Ruang Geografi : Kajian Artefak Dalam Geografi Sejarah”, Jurnal Sejarah Dan Budaya. Tahun Ketujuh, No. 2. Desember 2013.

Notoatmodjo, Soekidjo. 2003, Pengembangan Sumber Daya Manusia, Jakarta: PT. Rineka Cipta.

Pranoto, Suhartono.W. 2010. Teori \& Metodologi Sejarah. Yogyakarta: Graha Ilmu.

Putri, Agnes Ayu Santiana dkk. 2018. Sumber-Sumber Informasi Wisata Edukasi di Kota Palembang. Jurnal Pendidikan dan Pemberdayaan Masyarakat. Vol.5.No.1. Hal 1832.

Rachmatsyah. 2014. Menelaah Jejak Sejarah Langsa. Langsa. Sekretariat daerah kota Langsa.

Surat Keputusan Walikota Langsa Nomor 186/430/2016 yang ditetapkan di Langsa tanggal 7 Maret 2016 tentang Penetapan Gedung Pendopo sebagai Bangunan Cagar Budaya. 187/430/2016 yang ditetapkan di Langsa tanggal

7 Maret 2016 tentang Penetapan Gedung Satpol PP dan WH sebagai Bangunan Cagar Budaya.

188/430/2016 yang ditetapkan di Langsa tanggal

7 Maret 2016 tentang Penetapan Gedung Balee Juang sebagai Bangunan Cagar Budaya.

189/430/2016 yang ditetapkan di Langsa tanggal

7 Maret 2016 tentang Penetapan Gedung SD N 1 Kota Langsa sebagai Bangunan Cagar Budaya.

190/430/2016 yang ditetapkan di Langsa tanggal

7 Maret 2016 tentang Penetapan Tower PDAM Tirta Keumuneng sebagai Bangunan Cagar Budaya. 
Susanto, Heri. 2014. Seputar Pembelajaran Sejarah (Isi, Gagasan, Dan Strategi Pembelajaran). Banjarmasin : Aswaja Pressindo.

Suyatmin. (2014). Model Pengelolaan Kawasan Cagar Budaya Berbasis Kearifan Lokal untuk Memacu Daya Terik Wisata Budaya-Sejarah :Kasus di Kawasan KotaLama Semarang, Jawa Tengah. Surakarta: Universitas Muhamadiyah Surakarta.

Sjamsuddin, Helius. (2007). Metodologi Sejarah. Jakarta: Ombak.

Wartha, Ida Bagus Nyoman. 2016. "Manfaat Penting "Benda Cagar Budaya" Sebagai Peninggalan Sejarah/Arkeologi Untuk Kepentingan Agama, Sosial Budaya, Sosial Ekonomi, Pendidikan Dan Ilmu Pengetahuan (Studi Kajian Budaya)”, Jurnal Santiaga Pendidikan, Volume 6, No 2, Juli 2016.

Yass, Marzuki. (2004). Metodologi Sejarah Dan Histiografi. Palembang: Proyek SP4 Universitas Sriwijaya. 